\title{
PIRMINIŲ ONKOLOGINIŲ LIGONIŲ SVEIKATOS PRIEŽIŪROS OPTIMIZAVIMO GALIMYBĖS, TAIKANT ATVEJO VADYBA
}

\author{
Samanta Savickaitè ${ }^{1}$, Alvydas Česas ${ }^{2}$ \\ ${ }^{1}$ Klaipèdos universiteto Socialiniu ir humanitariniu mokslu fakultetas, \\ ${ }^{2}$ Klaipedos universitetine ligonine
}

\begin{abstract}
Raktažodžiai: pirminis onkologinis ligonis, atvejo vadyba, sveikatos priežiūros optimizavimas, onkologinių ligų trajektorija.
\end{abstract}

\begin{abstract}
Santrauka
Pasaulio sveikatos priežiūros sistemos ir organizacijos diegia ị asmenị orientuotos priežiūros modelị, siekdamos pagerinti veiklos rezultatus. Šis klausimas ypač svarbus onkologinių ligonių sveikatos priežiūrai dèl jos specifišskumo, kai sergančiujų išgyvenamumo ilginimo ir gyvenimo kokybės gerinimo tikslai skatina ịveikti procesu kompleksiškumą ir chaotiškumą diagnozės nustatymo ir gydymo etapuose. Tyrimo tikslas - įvertinti pirminiu onkologinių ligonių sveikatos priežiūros optimizavimo galimybes iš mokslinès ir praktinès perspektyvos, taikant atvejo vadybą. Sisteminès mokslinès literatūros, teisinių dokumentų ir klinikinès praktikos analizės duomenys atskleide, kad nuo onkologinès ligos įtarimo iki jos stebėsenos dalyvauja labai daug skirtingų lygmenų organizacijų, todèl ịgyvendinti nacionalinius paslaugų prieinamumo ir kokybès standartus fragmentiškoje aplinkoje pagal tradicinį sveikatos priežiūros modelį tampa neįmanoma. Didžiausias krūvis ir spaudimas tenka antrinio ir tretinio lygmens institucijoms, kurios pavieniui nepajègios įveikti iššūkius. Straipsnyje pristatomas Klaipedos universitetinejje ligoninejje sukurtas ir sèkmingai taikomas atvejo vadybos modelis pirminiams onkologiniams ligoniams, kaip priemonè, teikianti pagrindą onkologinių ligonių sveikatos priežiūros optimizavimui Lietuvoje.

Išvada - onkologijos atvejo vadybos modelio kūrimas ir diegimas - racionaliausia pirminių onkologinių ligonių problemų sprendimo alternatyva.
\end{abstract}

\section{İvadas}

XX a. pab. - XXI a. pr. pradèta kalbèti apie sveikatos priežiūros sistemų transformacijos poreikị, tačiau tuomet tai buvo labiau idèjiniai manifestai, ịtvirtinti $2001 \mathrm{~m}$. Jungtinių
Amerikos Valstijų medicinos instituto ataskaitoje. Nuo tada imta deklaruoti, kad sveikatos priežiūra turi būti labiau orientuota ị pacientą ir integrali, t.y. grịsta individualistine kompleksine prieiga, nes tai yra fundamentalus sveikatos priežiūros paslaugų kokybès standartas [1]. Dèl visuotinių tendencijų, tokių kaip gyventojų senèjimas, dauginès lètinès ligos ir jų gydymo bei valdymo problematika, išlaidos sveikatos priežiūrai auga milžinišku greičiu, todèl tradicinès sveikatos priežiūros sistemos nebepajègios ịveikti joms keliamus iššūkius [2,3]. Dèl šių esminių priežasčių i pacientą orientuotos sveikatos priežiūros idèjos sparčiai plètojamos, laipsniškai integruojamos ị pasaulinio ir nacionalinio lygmens strateginius dokumentus bei klinikinę praktiką, siekiant teikiamų sveikatos priežiūros paslaugų kokybės gerinimo ir sveikatos sistemos efektyvumo didinimo. Svarbu pabréžti, kad pastaraisiais metais mokslininkai ir praktikai pradejo vartoti jiems labiau priimtiną , ,i asmenị orientuotos sveikatos priežiūros" terminą apibrěžtị.

Viena iš pokyčių ịgyvendinimo prioritetinių sričių yra sergančiujų lètinėmis ligomis, tarp jų ir onkologinėmis, ị asmenị orientuota sveikatos priežiūra. Tiek Europos, tiek Atlanto pakrančių valstybėse sergamumo ir mirštamumo nuo onkologinių ligų rodikliai yra vieni didžiausių sveikatos statistikoje [4,5]. Didžiausią iššūkị kelia ne tik šių ligų gydymo kaštai, bet ir jų keliamų kompleksinių problemų valdymas skirtingose grandyse. Viena iš probleminių sričių, ypač svarbių antrinio ir tretinio lygmens sveikatos priežiūros įstaigoms - ankstyvoji naujų onkologinès ligos atvejų diagnostika ir gydymas. I̦vairiose šalyse ieškoma būdų ir priemonių, kaip optimizuoti onkologinių ligonių sveikatos priežiūrą, kad visos paslaugos nuo diagnostikos iki kontrolès etapo būtų suteiktos laiku, prieinamos, efektyvios ir integralios [6-8]. Atvejo vadyba šiuo atžvilgiu vis labiau pripažistama kaip neišvengiamas problemos sprendimo būdas.

Tyrimo tikslas - ịvertinti pirminių onkologinių ligonių 


\section{8}

sveikatos priežiūros optimizavimo galimybes iš mokslinès ir praktinès perspektyvos, taikant atvejo vadybą.

\section{Tyrimo medžiaga ir metodai}

Teorinejje ir analitinėje darbo dalyse integruotai taikyti dokumentų studijų, aprašomasis, statistinių duomenų analizès metodai.

\section{Tyrimo rezultatai}

Strateginės onkologinių ligonių sveikatos priežiūros kokybės gerinimo kryptys. Pasaulio sveikatos organizacija $2015 \mathrm{~m}$. nurodè 5 tarpusavyje susijusias strategines kryptis, taikytinas kuriant $i$ asmeni orientuotą ir integralią sveikatos priežiūros paslaugų infrastruktūrą. Tai 1) žmonių ịgalinimas ir ịtrauktis, 2) viešojo valdymo ir atskaitomybès stiprinimas, 3) priežiūros paslaugų modelio perorientavimas (nuo tradicinio link orientuoto ị asmenį), 4) paslaugų koordinavimas, 5) pokyčiams palankios aplinkos kūrimas [9, p. 20].

Norint nuosekliai ir sẻkmingai igyvendinti šias nuostatas konkrečiame kontekste, svarbu stebèti ir analizuoti kitų šalių politines tendencijas ir organizacinę praktiką. Pavyzdžiui, Australijoje, kur onkologinių ligonių išgyvenamumas yra vienas didžiausių pasaulyje, akcentuojama mokslinių tyrimų svarba, ieškant pagrįstų ir tvarių priežiūros teikimo modelių. Nacionaliniu lygmeniu pabrežiama tarpsektorinès partnerystės ir onkologine liga sergančių asmenų priežiūros koordinavimo reikšmè, siekiant efektyviai ịveikti esamus ir būsimus vėžio kontrolès iššūkius, išvengti išteklių švaistymo ir paslaugu dubliavimosi, aktyviai ịtraukiant visus galimus suinteresuotus subjektus: vyriausybę, pacientų organizacijas, nevyriausybines organizacijas, bendruomenes, privačius paslaugų teikèjus, tyrimų institutus [10]. Galima stebèti, kaip šalyje intensyviai plètojama kompleksinès pagalbos infrastruktūros sistema, ieškoma optimaliausių paslaugų teikimo būdų.

Europos tarptautiniuose strateginiuose dokumentuose taip pat labai aiškiai atsispindi i a asmeni orientuotos sveikatos priežiūros nuostatos. Labai plačiai aptariami visi aktualūs aspektai nuo onkologinių ligų prevencijos iki onkologinių ligonių gyvenimo kokybès, baigus gydymą. Iš konteksto tikslinga išskirti multidisciplininès prieigos taikymo poreikị, koordinuojant skirtingų paslaugos teikejų veiksmus ir igalinant asmenis, sergančius onkologinemis ligomis. Teigiama, kad viena iš svarbesnių priemonių sẻkmingų pokyčių link - atvejo vadybininko įdarbinimas, ji priskiriant kiekvienam pacientui, kad būtų galima efektyviu būdu atliepti ị kompleksinius sergančiojo poreikius ir optimizuoti jo trajektoriją, t.y. kelią nuo ligos įtarimo iki gydymo ir kontrolès $[7,11,12]$.

I asmenį orientuota onkologinių ligonių sveikatos priežiūra plačiu mastu ir ambicingai kuriama Anglijoje. Ši valstybe pasižymi labai stipriu holistiniu požiūriu onkologijoje, yra pasiekusi ženklią pažangą, lyginant su kitomis Europos valstybėmis, todèl kai kuriais atžvilgiais laikytina gerosios praktikos pavydžiu. Nacionalinèje onkologinių ligonių sveikatos priežiūros politikoje įtvirtintos bazinès principinès nuostatos, tokios kaip priežiūros individualizacija ir personalizacija, koprodukcija [13] ippareigojo perprojektuoti buvusių paslaugų infrastruktūrą, steigti agentūras bei vykdyti daugeli kitų pokyčių. Didžiausios pasaulinio garso labdaros organizacijos „Macmillan Cancer Support" atliktoje studijoje nustatyta nemažai problemų, kurios sunkina strateginių idejų praktini igyvendinimą šalyje. Kaip vienos iš svarbiausių, aktualios daugeliui valstybių, išskirtos: neaiškus atsakomybès padalijimas tarp skirtingų institucijų, vietinio ir nacionalinio lygmens prioritetų neatitiktis, lyderystės vykdyti pokyčius stoka, finansavimo trūkumas vietiniu lygmeniu, darbo jègos trūkumas, kuris ypač neigiamai atsiliepia diagnostikos, pagalbos prieinamumo ir koordinavimo procesams [14].

Ivairios studijos rodo, kad sudarant ilgalaikius onkologiniu ligonių sveikatos priežiūros planus, būtinas realistinis požiūris - suvokimas, kad perspektyvoje žmonių, sergančių onkologine ir gretutinėmis ligomis skaičius augs, todèl jiems bus būtinos kompleksinès paslaugos ir ị asmenị orientuota prieinama paslaugų infrastruktūra. Atitinkamai būtina suteikti pirmenybę efektyviai gydymo ir socialinès priežiūros paslaugų integracijai ir koordinavimui, klinikinių slaugytojų skaičiaus didinimui, paciento patirčių ir gyvenimo kokybės gerinimui [15].

Atvejo vadyba kaip strateginis onkologinių ligoniụ sveikatos priežiūros sprendimas. Sveikatos priežiūra - labai sudètingas ịvairių paslaugos teikèjų tinklas, sudarytas iš pirminio, antrinio, tretinio lygmens institucijų, nevyriausybinių organizacijų, privačių įstaigų ir kitų suinteresuotujų subjektų. Nereikètų nuvertinti šio painaus tinklo elementų bendradarbiavimo problematikos. Iš pažiūros gali atrodyti, kad ìvairių specialistų, institucijų bendradarbiavimas yra savaime suprantamas dalykas, vis dėlto šių procesų koordinavimas dar nesulaukia reikiamo dèmesio. Tam, kad skirtingi šị tinklą sudarantys subjektai judètų bendra strategine kryptimi, būtina suderinti jų skirtingas darbotvarkes. Efektyvus sveikatos priežiūros organizacijų ir kitų suinteresuotujų subjektų grandinès valdymas yra būtinas ịveikti kompleksines problemas bei sukurti palankią bendradarbiavimo aplinką [16]. Ypač tai aktualu kuriant ị asmenị orientuotą sveikatos priežiūrą, kurioje svarbus tarspektorinis bendradarbiavimas ir paslaugu integralumas [17].

Praktinio lygmens paslaugų integralumo ir koordinavimo siekiai igyvendinami taikant atvejo vadybos modelį. Jo sèkmè ịvairiose klinikinèse srityse suteikè racionalų pagrindą šios prieigos adaptacijai onkologijoje. Teigiama, kad onkologinès ligos atvejo vadyba specialistams ir pacientams yra labai svarbi tarpinè grandis, jungianti skirtingų specialistų 


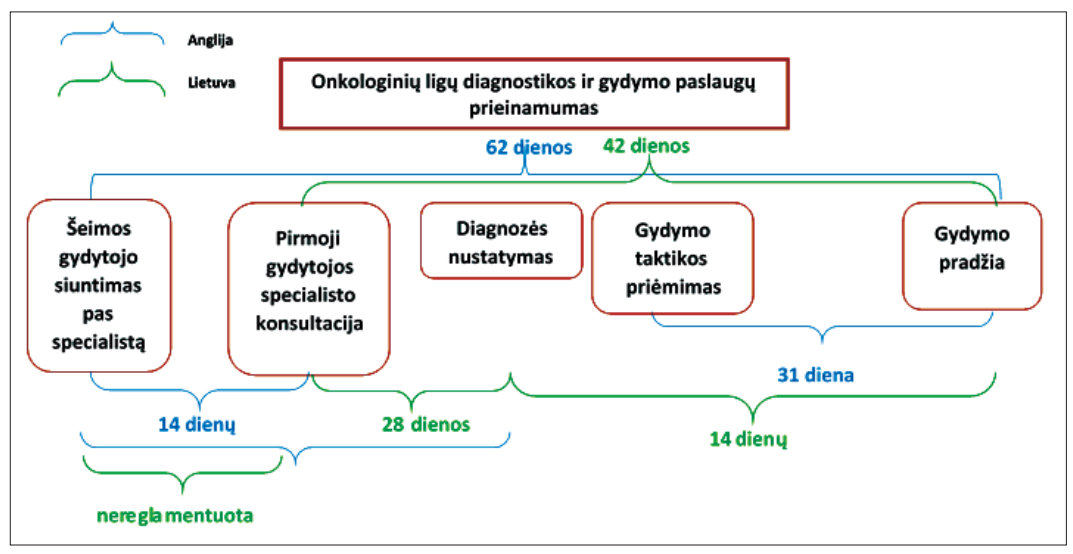

1 pav. Onkologinių ligų diagnostikos ir gydymo paslaugų prieinamumo standartai Anglijoje ir Lietuvoje Sudaryta darbo autoriu.

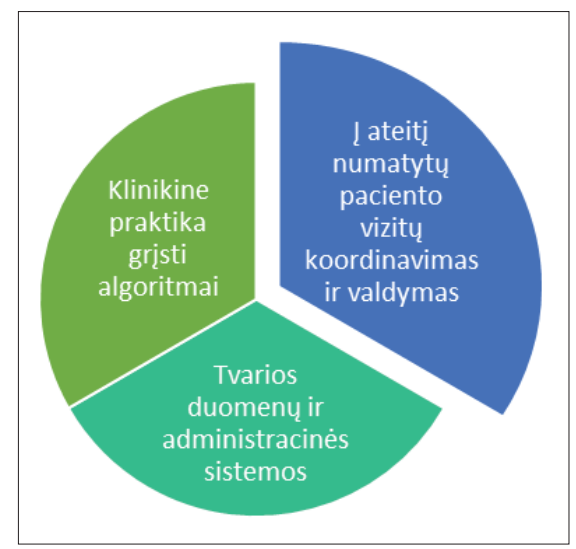

2 pav. Efektyvaus onkologinių ligonių trajektorijos valdymo dedamosios Šaltinis: [25].

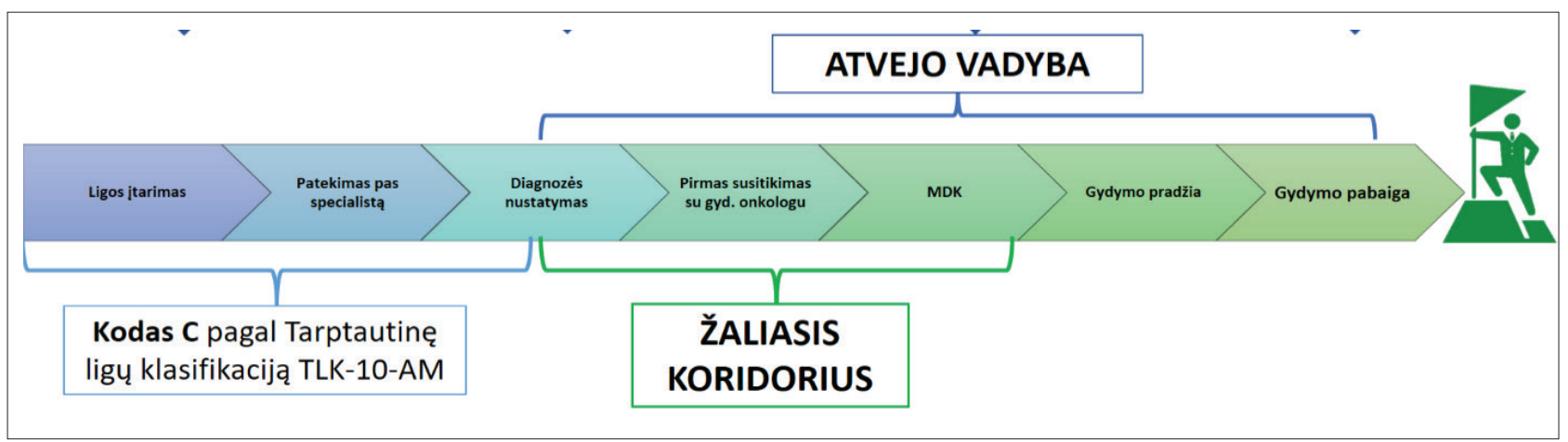

3 pav. Klaipėdos universitetinès ligoninès „Žaliojo koridoriaus“ registravimosi sistema Šaltinis: Sudaryta darbo autoriu.

teikiamą pagalbą ị darnų planą [18]. Mokslinèje literatūroje išskiriama ganètinai daug atvejo vadybos modelių, kurie skirstomi ị ịvairiausias kategorijas ir tipus. Visi modeliai turi tam tikrų panašumų ir skirtumų, priklausomų nuo organizacinio konteksto, kuriame konkretus modelis yra kuriamas, ypatumy [19]. Pačia bendriausia prasme atvejo vadyba suprantama kaip sveikatos priežiūros specialisto (atvejo vadybininko) vykdoma aktyvi paciento, turinčio kompleksinių poreikių, stebėsena, apimanti pacientui būtinos pagalbos paslaugų plano sudarymo ir jo ịgyvendinimo tarp skirtingų paslaugos teikèjų koordinavimo procesus [20]. Ši veikla aprepia tarpdisciplininès komandos formavimą ir jos narių bendradarbiavmo plètrą, paslaugų koordinavimą, individualias intervencijas, tokias kaip paciento palaikymas, informavimas ir švietimas. Visi šie baziniai procesai siejami su onkologinių ligonių trajektorijos optimizavimu [21], kuris turètų būti suprantamas plačiaja prasme, kai liečiami paslaugų prieinamumo, savalaikiškumo, tikslingumo ir integralumo aspektai.

Atvejo vadybos taikymas, optimizuojant pirminių onkologinių ligonių trajektoriją. Onkologinių ligonių sveikatos priežiūra yra probleminè dèl jos specifiškumo. Kalbama ne tik apie pažangiausių gydymo metodų nuolatines paieškas, siekiant pailginti sergančiujų išgyvenamumą ar palaikyti jų gyvenimo kokybės gerinimo siekį, bet ir apie procesų kompleksiškumą ir chaotiškumą, trukdantị kuo operatyviau nustatyti ligos diagnozę ir pradèti gydymą. Pastarasis aspektas ypač aktualus specializuotoms antrinio ir tretinio lygmens institucijoms, kurių atžvilgiu keliami ganètinai aukšti sveikatos politikos reikalavimai. Nuo ligos įtarimo iki stebėsenos dalyvauja labai daug skirtingo lygmens organizacijų [22], todèl galimybė igyvendinti nacionalinius standartus fragmentiškoje aplinkoje pagal tradicini sveikatos priežiūros modelị tampa utopinè [23].

Pavyzdžiui, Anglijoje numatytas 62 kalendorinių dienų terminas nuo diagnozès įtarimo iki pirmojo gydymo pradžios. Per ṣ̨̌ laikotarpị turi būti ịvykdyti 3 reikalavimai: esant ligos itarimui, pacientas šeimos gydytojo siuntimu per 14 dienų turi patekti specialisto ištyrimui (1); ne vèliau kaip per 2 savaites pacientui turi būti nustatyta tiksli diagnozè (2); per 31 dieną turi būti pradètas gydymas (3) [24,25]. Akivaizdu, kad 
Anglijoje didžiulis spaudimas tenka diagnostikos paslaugas teikiančioms institucijoms. Skirtingai nei Anglijoje, Lietuvos sveikatos apsaugos ministro $2017 \mathrm{~m}$. ịsakyme V-156 „Dèl onkologinių ligų diagnostikos ir gydymo paslaugų prieinamumo ir kokybès rodikliu ir jų stebėsenos tvarkos aprašo patvirtinimo" [26] dèmesys skiriamas laikotarpiui nuo patekimo pas gydytoją specialistą iki diagnozės nustatymo (iki 28 kalendorinių dienų) ir nuo diagnozès nustatymo iki gydymo pradžios (iki 14 kalendorinių dienų). Nors dokumente apibrezžtas 42 kalendorinių dienų intervalas, tačiau jame neatsispindi laiko reikalavimas, per kuri pacientas su šeimos gydytojo siuntimu turi patekti specialisto konsultacijai, o tai svarbus visos trajektorijos momentas (1 pav.).

Ką valstybei reiškia neapibrež̌tas laiko intervalas, per kurị pacientas, turintis šeimos gydytojo, ịtarusio onkologinị susirgimą, siuntimą, patektų pas gydytoją specialistą? Tikètina, kad pacientas atvyks planine tvarka. Pasitvirtinus diagnozei, galima spèti apie jo nepasitenkinimą dèl laukimo eilių ir sistemos nepalankumo sergantiesiems. Neretai patirtas chaosas, nerimas, pyktis ir kiti negatyvūs dalykai pasiekia specializuotas gydymo įstaigas, kuriose gydymo pradžia priklauso nuo turimų duomenų, jau atlikto ištirtumo. Formuojasi trikdžių ir iššūkių grandinè, stipriai veikianti sveikatos priežiūros įvaizdị ir kokybę, tad norint užtikrinti prieinamą ir savalaikę pagalbą

\begin{tabular}{|c|c|c|}
\hline Struktūra & Procesai & $\begin{array}{l}\text { Siekiami } \\
\text { rezultatai }\end{array}$ \\
\hline $\begin{array}{l}\text { Onkologijos atvejo } \\
\text { vadybininko įdarbinimas }\end{array}$ & $\begin{array}{l}\text { Paciento informavimas, } \\
\text { veiksmų koordinavimas }\end{array}$ & $\begin{array}{l}\text { Paslaugų prieinamumo ir } \\
\text { savalaikiškumo } \\
\text { didinimas }\end{array}$ \\
\hline $\begin{array}{l}\text { Patvirtinta onkologijos } \\
\text { vadybininko veiklos } \\
\text { tvarka }\end{array}$ & $\begin{array}{l}\text { Kompleksines pagalbos } \\
\text { planavimas ir } \\
\text { organizavimas }\end{array}$ & $\begin{array}{l}\text { I asmenị orientuotos } \\
\text { priežiūros kūrimas }\end{array}$ \\
\hline $\begin{array}{l}\text { Atskira „Žaliojo } \\
\text { koridoriaus“ registracijos } \\
\text { sistema }\end{array}$ & $\begin{array}{l}\text { Psichosocialinis } \\
\text { konsultavimas, distreso } \\
\text { vertinimas }\end{array}$ & $\begin{array}{l}\text { Pagerèjusi paslaugų } \\
\text { kokybė }\end{array}$ \\
\hline $\begin{array}{l}\text { Fizinè infrastruktūra } \\
\text { onkologijos vadybininkui } \\
\text { (atskiras nuolatinis } \\
\text { kabinetas telefono liniia }\end{array}$ & $\begin{array}{l}\text { Bendradarbiavimo su } \\
\text { tarpdisciplininès } \\
\text { komandos specialistais }\end{array}$ & $\begin{array}{l}\text { Padidèjęs pacientų } \\
\text { pasitenkinimas } \\
\text { paslaugomis }\end{array}$ \\
\hline el. paštas) & Priežiūros integravimas & Tikslingas ištekliu \\
\hline $\begin{array}{l}\text { Vidiniu , ,hide“ talonų } \\
\text { sistemos plëtra }\end{array}$ & & panaudojimas \\
\hline $\begin{array}{l}\text { Suburta ir plètojama } \\
\text { gydytojų specialistų } \\
\text { komanda }\end{array}$ & $\begin{array}{l}\text { plètojimas su } \\
\text { suinteresuotomis } \\
\text { institucijomis (NVO, } \\
\text { savivaldybe ir kt.) }\end{array}$ & $\begin{array}{l}\text { Organizacijos veiklos } \\
\text { rodiklių ir ịvaizdžio } \\
\text { gerinimas }\end{array}$ \\
\hline $\begin{array}{l}\text { Sudaromos sąlygos } \\
\text { stažuotėms, vykdoma } \\
\text { mokslinė veikla }\end{array}$ & $\begin{array}{l}\text { Nuolatinis vykdomų } \\
\text { procesų vertinimas ir } \\
\text { tobulinimas }\end{array}$ & \\
\hline $\begin{array}{l}\text { Suburta psichosocialinès } \\
\text { pagalbos specialistų } \\
\text { komanda }\end{array}$ & & \\
\hline
\end{tabular}

4 pav. Onkologijos atvejo vadybos Klaipėdos universitetineje ligoninejje sistema

Šaltinis: sudaryta darbo autoriu. onkologiniams ligoniams, būtina priimti sprendimus, susijusius su naujų pacientų (t.y. pirminių onkologinių ligonių) trajektorijos optimizavimu. Apskritai vertinant onkologinę sveikatos priežiūros paslaugų sistemą, tyrimai rodo diagnostikos ir gydymo etapu svarbą visame onkologinès ligos trajektorijos kontekste [27].

Ivairiose studijose nustatyta, kad siekiant spręsti šią problemą ir užtikrinti greitesnę onkologinès ligos gydymo pradžią, organizacijose svarbu užtikrinti tam tikrujų dedamuju egzistavimą (2 pav.). Kartu būtinas tikslingas ir išsamus pacientu informavimas apie vykstančius procesus, optimaliausio paslaugų teikimo modelio paieškos, organizacijos aprūpinimas reikiamais ištekliais [28].

Diagnostikos ir gydymo etapų efektyvumą gali padidinti inovatyvi vadyba, keičiant požiūrị ị paslaugų valdymo prieigą [25], todèl randasi atvejo vadybininko, kaip sveikatos priežiūros specialisto, poreikis. Jo veikla organizacijai teikia strategini pranašumą, igalina operatyviai ir sklandžiai vykdyti numatytas užduotis, sudaro lemiamas sąlygas ị asmeni orientuotos sveikatos priežiūros kūrimui praktiniu lygmeniu. Deja, žmogiškujų išteklių problema visame pasaulyje iškeliama kaip prioritetinè sritis, ypač kalbant apie tokius specialistus kaip atvejo vadybininkai $[27,29]$. „Žaliojo koridoriaus“ atvejo vadyba Klaipėdos universitetinèje ligoninèje. $2019 \mathrm{~m}$. sausio $2 \mathrm{~d}$. Klaipédos universitetinèje ligoninèje savanorystès pagrindu pradètas vykdyti bandomasis projektas, kurio metu, remiantis moksliniais tyrimais ir gerosios praktikos pavyzdžiais, buvo kuriama onkologijos atvejo vadybininko pareigybe darbui su naujais (t.y. pirminiais) onkologiniais ligoniais, ị ịstaigą užsiregistravusiais ,Žaliojo koridoriaus" sistemoje (3 pav.). Vyriausiojo gydytojo ịsakymu patvirtinta vyresniojo specialisto (onkologijos atvejo vadybininko) pareiginè instrukcija [30] ir Kompleksinès pagalbos paslaugų onkologiniams pacientams teikimo tvarkos aprašas [31], kurių pagrindu ligoninėje plètojama onkologijos paslaugų vadyba. 2019 m. rugpjūčio mèn. vidine tvarka ịsteigta onkologijos atvejo vadybininko pareigybè darbui 0,5 etatu, kuris $2020 \mathrm{~m}$. pavasarị padidintas iki 1,0 etato. Per tą laikotarpi koordinuota daugiau nei 300 pacientų, 250 iš jų buvo reikalingas išsamus ištyrimas prieš planuojamą gydymą. 204 pacientams suteiktos išsamios psichosocialinio pobūdžio konsultacijos [32].

Tolesnè onkologijos atvejo vadyba pletojama A. Donabedian sveikatos priežiūros kokybės vertinimo modelio pagrindu [33, 34], ị kurị orientuotasi kuriant Klaipédos universitetinès ligoninès onkologinių ligonių atvejo vadybos struktūrą, procesus ir siekiamus rezultatus (4 pav.).

Pas atvejo vadybininką pirminiai onkologiniai ligoniai patenka užsiregistruodami „Žaliojo koridoriaus“ 
sistemoje arba atsiųsti gydytojo onkologo chemoterapeuto. Atvejo vadybininko veiklą sudaro kontaktinès ir nekontaktinès darbo valandos. Kontaktinio darbo metu su pacientais bendraujama telefonu, el.ryšių priemonėmis bei tiesioginès konsultacijos metu. Pirminè, tiesioginè onkologijos atvejo vadybininko konsultacija pacientui paskiriama po pirmo vizito pas gydytoją onkologą chemoterapeutą ir (ar) radioterapeutą. Vidutinè konsultacijos trukmè apie 60 min., kurios metu su pacientu aptariama tolesnè tyrimų ir (ar) gydymo eiga, suteikiama aktuali informacija dèl pasiruošimo numatytoms procedūroms. Po to - išsamus psichosocialinis konsultavimas, apimantis ir paciento patiriamo distreso vertinimą. Atsižvelgiant ị konsultacijos metu aptartus dalykus, prioritetine tvarka onkologijos atvejo vadybininkas kartu su pacientu sudaro kompleksinès pagalbos planą, kuriame įtraukiamos ir psichosocialinès pagalbos specialistų konsultacijos (dažniausiai klinikinio psichologo, gydytojo dietologo, rečiau - dvasininko, socialinio darbuotojo), pacientui perduodama aktuali dalomoji informacinė medžiaga. Vidutiniškai per dieną onkologijos atvejo vadybininkas teikia 3-4 tiesiogines pirmines konsultacijas visiškai naujiems pacientams, tačiau šis skaičius kinta ir gali išaugti iki 8 konsultacijų per dieną, priklausomai nuo pacientų srauto [30-32].

Nekontaktinio darbo metu atliekamos ịvairios funkcijos ir užduotys: koordinuojami pirminių pacientų srautai (vykdoma pacientų atranka: vertinama pateikta paciento ligos istorijos dokumentacija pagal numatytus algoritmus), atliekama registracija diagnostiniams tyrimams ir specialistų konsultacijoms, stebimi ir koordinuojami su pacientų diagnostika ir gydymu susiję procesai, renkami pacientui atliktų diagnostinių tyrimų rezultatai, kurie suvedami ị multidiciplininès komandos konsiliumų sistemą nustatyti gydymo taktiką. Jei reikia, atvejo vadybininkas renka pacientui aktualią informaciją gyvensenos ir kitais klausimais, domisi pagalbos galimybemis kitose ịstaigose, plètoja bendradarbiavimą su suinteresuotomis institucijomis dèl pacientu gyvenimo kokybės gerinimo [30,31].

Onkologijos atvejo vadybininkui tenka atsakomybè reguliariai tikrinti pacientų registravimosi „Žaliajame koridoriuje“ tikslingumą, analizuoti „Žaliojo koridoriaus“ paslaugu teikimo kokybinius ir kiekybinius rodiklius, pirminiams pacientams reikalingų diagnostinių tyrimų ir konsultacijų mastą bei pokyčius, skatinti pacientų švietimą ir aktyvų dalyvavimą onkologinès ligos gydymo procesuose. Klaipėdos universitetinejje ligonineje siekiama, kad kiekvienas pirminis onkologinis ligonis gautų visapusị palaikymą, operatyvią ir kokybišką pagalbą. Dedamos pastangos, kad nuo pirmo kreipimosi ị gydymo ịstaigą pacientas pas reikalingą specialistą petektų ne vèliau, kaip per 5 darbo dienas. Jei reikalingas papildomas diagnostinis ištyrimas (KT, MRT, scintigrafija ir pan.), ilgiausia vidutinė šių tyrimų laukimo trukmė yra 10 darbo dienų. Atlikus tyrimus ir gavus visus atsakymus, paciento atvejis pristatomas artimiausiam kassavaitiniam multidisciplininès komandos aptarimui [30,32].

Onkologijos atvejo vadybininko veikla aprépia platų onkologinių ligų profilį,tačiau yra bandomojo pobūdžio visos šalies mastu. Nesant vieningos ir išmanios informacinès sistemos, darosi problematiška kaupti ir sisteminti ịvairialypę informaciją, kurios pagrindu būtų galima plètoti šią veiklą ir dar labiau optimizuoti procesus,

Atvejo vadybos modelis vis dažniau pradedamas taikyti sveikatos priežiūros organizacijose kaip kompleksinius poreikius turinčių asmenų sveikatos priežiūros kokybės gerinimo priemonè. Onkologijos atvejo vadybininko veikla prisideda prie strategiškai pozityvių pokyčių, susijusių su pacientų pasitenkinimu teikiama sveikatos priežiūra, įstaigoje vykstančių procesų optimizacija, specialistų darbo kokybe.

\section{Išvados}

1. Sveikatos priežiūros sektorius yra smarkiai veikiamas pasaulinių strateginių tendencijų dèl ị asmenị orientuotos prieigos taikymo. Holistinis požiūris, paslaugų integralumas traktuojami kaip kertiniai principai, kurių pagrindu turi būti vykdomi transformaciniai pokyčiai ir klinikinejje onkologijos praktikoje.

2. Išskirtinai problemine sritimi visoje onkologinių ligų trajektorijoje ịvardijama diagnostika ir gydymas, todèl antrinè ir tretinè sveikatos priežiūros grandys patiria kone didžiausią krūvị ir spaudimą.

3. Pasaulinè praktika ir tyrimai rodo atvejo vadybos vertę ir naudą, siekiant geriau spręsti onkologinių ligonių sveikatos priežiūros problemas.

4. Klaipėdos universitetinejje ligoninëje sukurtas ir pradetas taikyti bandomasis atvejo vadybos modelis pirminiams onkologiniams ligoniams laikytinas itin sékminga ir pasiteisinusia priemone, turinčia pagrindą tolesnei plètrai, sprendžiant onkologinių ligonių sveikatos priežiūros optimizavimo problemas Lietuvoje.

\section{Literatūra}

1. Baker A. Crossing the quality chasm: a new health system for the 21 st century. BMJ 2001;323(7322):1192.

https://doi.org/10.1136/bmj.323.7322.1192

2. Ebel T, Katy G, Larsen E, Shah K, Ungerman D. Building new strengths in the healthcare supply chain: pharmaceuticals and medical products operations. McKinsey \& Co 2013.

3. Kumar R, Chattu V. What is in the name? understanding terminologies of patient-centered, person-centered, and patientdirected care! Journal of Family Medicine and Primary Care 2018;7(3):487-488. 
https://doi.org/10.4103/jfmpc.jfmpc_61_18

4. Siegel RL, Miller KD, Jemal A. Cancer statistics, 2019. CA: A Cancer Journal for Clinicians 2019;69(1):7-34.

https://doi.org/10.3322/caac.21551

5. World Health Organisation. Cancer: key facts.

https://www.who.int/news-room/fact-sheets/detail/cancer.

6. European Kommission. Europe's beating cancer plan roadmap. https://ec.europa.eu/info/law/better-regulation/have-your-say/ initiatives/12154-Europe-s-Beating-Cancer-Plan.

7. Albreht T, Kiasuwa T, Bulcke MV. European guide on quality improvement in comprehensive cancer control. El. book - Ljubljana: National Institute of Public Health; Brussels: Scientific Institute of Public Health 2017.

8. Mcavoy B. Optimising cancer care in Australia. Aust Fam Physician 2003;32(5):369.

9. World Health Organization. WHO global strategy on peoplecentred and integrated health services. WHO 2015:1-50.

10. Cancer Australia, Australian government. Cancer Australia strategic plan 2014-2019.

11. European Commission. Europe's beating cancer plan: roadmap. 2020. https://ec.europa.eu/info/law/better-regulation/haveyour-say/initiatives/12154-Europe-s-Beating-Cancer-Plan.

12. Nolte E, Knai C, Saltman RB, editors. Assessing chronic disease management in European health systems: concepts and approaches. Copenhagen (Denmark): European Observatory on Health Systems and Policies 2014.

13. Achieving world-class cancer outcomes. A strategy for England 2015-2020. NHS 2015.

14. Macmillan Cancer Support. Warning signs challenges to delivering the cancer strategy for England by 2020. Macmillan Cancer Support 2017.

15. Macmillan Cancer Support. One size does not fit all: why we need to make cancer care in the NHS more personal. 2020.

https://www.macmillan.org.uk/_images/one-size-doesnt-fitall-report-web tcm9-341625.pdf

16. Marques L, Martins M, Araújo C. The healthcare supply network: current state of the literature and research opportunities. Production planning \& control 2020;31(7):590-609.

https://doi.org/10.1080/09537287.2019.1663451

17. Meijboom B, Schmidt-Bakx S, Westert G. Supply chain management practices for improving patient-oriented care. Supply Chain Management: An International Journal 2011;16(3):166175.

https://doi.org/10.1108/13598541111127155

18. Pei-Yi L, Chang T. Application of integrative information system improves the quality and effectiveness of cancer case management. Journal of Multidisciplinary Healthcare 2015;8:287-290.

https://doi.org/10.2147/JMDH.S77714

19. Huber DL. The diversity of case management models. Lippincotts Case Manag 2002;7(6):212-220. https://doi.org/10.1097/00129234-200211000-00002

20. Krumholz HM, Currie PM, Riegel B, et al. A taxonomy for disease management: a scientific statement from the American Heart Association disease management taxonomy writing group. Circulation 2006;114(13):1432.

https://doi.org/10.1161/CIRCULATIONAHA.106.177322

21. Wulff CN, Thygesen M, Søndergaard J, Vedsted P. Case management used to optimize cancer care pathways: a systematic review. BMC Health Services Research 2008;8:227.

https://doi.org/10.1186/1472-6963-8-227

22. Payne HA, Farnham C, Kirby M, Troup J. Advanced prostate cancer - optimising and integrating care. Trends in Urology \& Men's Health 2013;4(1):36-40.

https://doi.org/10.1002/tre.314

23. Santana MJ, Manalili K, Jolley RJ, Zelinsky S, Quan H, Lu M. How to practice person-centred care: a conceptual framework. Health Expectations 2018;21(2):429-440.

https://doi.org/10.1111/hex.12640

24. NHS England. National cancer waiting times monitoring dataset guidance V.11.0. 2020. https://www.england.nhs.uk/statistics/ wp-content/uploads/sites/2/2020/09/national-cancer-waitingtimes-monitoring-dataset-guidance-v11-sep2020.pdf

25. NHS. Sustaining cancer waiting times through effective pathway management, 2017. https://www.england.nhs.uk/ improvement-hub/publication/sustaining-cancer-waiting-times-through-effective-pathway-management/

26. LR sveikatos apsaugos ministro $2017 \mathrm{~m}$. vasario $17 \mathrm{~d}$. įsakymas Nr. V-156 Dèl onkologinių ligų diagnostikos ir gydymo paslaugų prieinamumo ir kokybės rodiklių ir jų stebėsenos tvarkos aprašo patvirtinimo. TAR, 2017-02-20 Nr. 2017-02787.

27. NHS. Health education England. Strategic framework for cancer workforce. Interim working paper July 2018, not official or final HEE position.

28. NHS England. Implementing a timed lung cancer diagnostic pathway 2018.

29. NHS England and NHS improvement. Rapid diagnostic centres vision and 2019/20 implementation specification. 2019.

30. VšI Klaipėdos universitetinès ligoninès vyresniojo specialisto (onkologijos atvejo vadybininko) pareiginè instrukcija, 2019.

31. Vš I Klaipėdos universitetinès ligoninès vyriausiojo gydytojo 2019 m. ịsakymas Nr. 248 Dẻl kompleksinès pagalbos paslaugu onkologiniams pacientams teikimo tvarkos aprašo patvirtinimo.

32. VšI Klaipėdos universitetinès ligoninès onkologijos atvejo vadybininko 2019 m. rugpjūčio - 2020 m. rugsejjo veiklos ataskaita.

33. Donabedian A. Evaluating the quality of medical care. Milbank Q 2005;83(4):691-729. https://doi.org/10.1111/j.1468-0009.2005.00397.x

34. NHS Improvement. Model for measuring quality care (structure, process, outcome and balancing measures). 2018. 


\section{OPTIMIZING PRIMARY CANCER PATIENTS $`$ HEALTH CARE BY THE APPLICATION OF CASE MANAGEMENT

\author{
S. Savickaitè, A. Česas
}

Keywords: primary cancer patient, case management, health care optimization, cancer pathway.

Summary

Globally, health care systems and organizations are looking to improve their performance through the implementation of a person-centred care model. This issue is particularly important for cancer care due to its specificity, as its agenda intertwines not only the goals of prolonging the survival rates, improving patient's quality of life, but also overcoming the complexity and chaos of processes in the diagnosis and treatment stages. Moreover, as a wide range of organizations at different levels are involved in the cancer pathway from disease suspition to surveillance, it becomes almost impossible to implement national standards for accessible and comprehensive cancer care in an old-fashioned and fragmented environment that is based on the traditional health care model. Unfortunately, the greatest pressure falls on secondary and tertiary institutions, which alone are unable to meet the challenges. In regards to this, by the application of person-centred approach in organizational practice, the development of cancer case management model is playing an increasingly important role as the most rational solution.

The aim of the study: through scientific and practical lenses, to evaluate the possibilities of optimizing primary cancer patients health care by applying the case management.

Correspondence to: samantasavickaite@yahoo.com

Gauta 2020-11-26 